\title{
The Land Snails of a Small Tropical Pacific Island, Aunu'u, American Samoa ${ }^{1}$
}

\author{
Robert H. Cowie ${ }^{2}$ and Rebecca F. Rundell ${ }^{3}$
}

\begin{abstract}
Survey work on the American Samoan island of Aunu'u, a small island off the eastern end of Tutuila, combined with review of museum collections, increased the known land snail fauna of the island from 2 to 22 species. Of these species, 12 are native to the Samoan Archipelago, nine are introduced, and one is cryptogenic (of unknown origin). The fauna is a subset of that of the main American Samoan island of Tutuila, although it also includes one species endemic to Aunu'u but now extinct.
\end{abstract}

The Samoan Archipelago lies in the south-central Pacific Ocean and is divided politically between Samoa (formerly Western Samoa) and American Samoa. The native land snail fauna of the Islands exhibits a high level of endemism, but a number of widespread alien species are also present (Cowie 1998).

Recent survey work has documented the current status of land snail biodiversity on the American Samoan islands of Tutuila, Ofu, and Ta'u (Cowie and Cook 1999, 2001, Cowie 2001), and Olosega (Cowie et al. in press), demonstrating the precarious nature of some of the species, the decline of most native species, and the increase and continued introduction (Cowie 2001) of a relatively

${ }^{1}$ Contribution no. 2001-011 of Bishop Museum's Pacific Biological Survey. This work was funded in part by the U.S. National Science Foundation (grant no. DEB 9705494). Manuscript accepted 15 August 2001.

2 Bishop Museum, 1525 Bernice Street, Honolulu, Hawaili 96817. Current address: Center for Conservation Research and Training, University of Hawai'i at Mānoa, 3050 Maile Way, Gilmore 409, Honolulu, Hawai'i 96822 (phone, 808-956-4909; fax, 808-956-2647; E-mail, cowie@hawaii.edu).

${ }^{3}$ Department of Zoology, University of Hawai'i at Mānoa, Honolulu, Hawaíi 96822. Current address: Committee on Evolutionary Biology, University of Chicago, 1025 E. 57th Street, Culver 402, Chicago, Illinois 60637.

Pacific Science (2002), vol. 56, no. 2:143-147 (C) 2002 by University of Hawai'i Press.

All rights reserved small number of widespread alien species. This paper focuses on the small $\left(1.6 \mathrm{~km}^{2}\right)$ island of Aunu'u, which lies $1.2 \mathrm{~km}$ off the eastern end of Tutuila, the main island of American Samoa (Figure 1).

Almost nothing has been published on the land snails of Aunu'u, despite its close proximity to and accessibility from Tutuila. Only two species have been reported, both by Solem (1983): the endemic charopid Sinployea aunuuana, and the widespread Pacific charopid Discocharopa aperta, both collected in 1926 and deposited in the Bishop Museum (Honolulu) mollusk collections. A number of additional species are also present in the Bishop Museum collections, but have never been reported in the literature.

In this paper we report on the land snail species collected during fieldwork on Aunu'u, provide a faunal inventory for the island, including species previously collected, and discuss the fauna of Aunu'u in the context of its close proximity to Tutuila.

\section{MATERIALS AND METHODS}

Field survey work was undertaken on Aunu'u in February 2001. Samples of snails were taken at 10 locations (Figure 2). These locations ranged from sea level to $58 \mathrm{~m}$ in elevation and from lowland coastal habitats to native forest at higher elevations and to cultivated midelevation habitats.

Collecting protocols followed Cowie and Cook (1999, 2001), Cowie (2001), and Cowie et al. (in press), essentially involving timed 


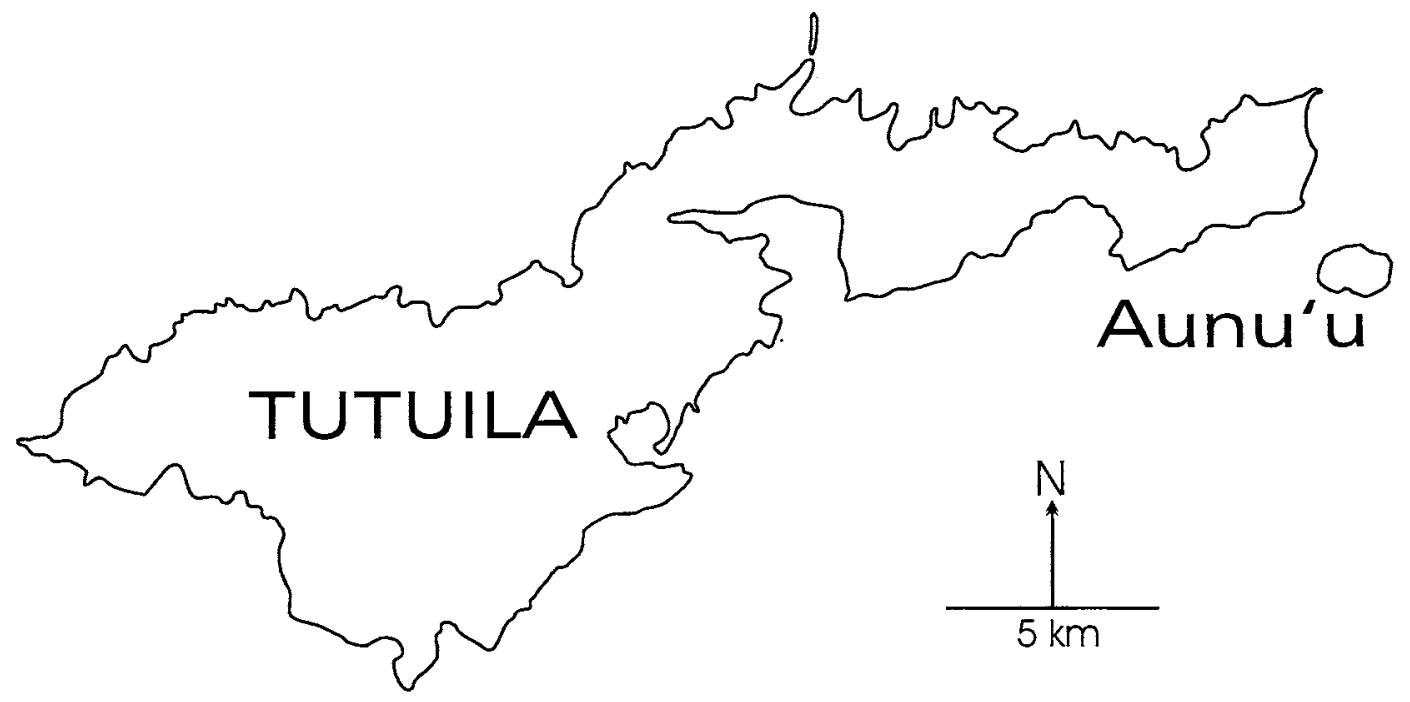

Figure 1. Tutuila and Aunu'u. The islands lie between $170^{\circ}$ and $171^{\circ} \mathrm{W}$ and between $13^{\circ}$ and $14^{\circ} \mathrm{S}$.

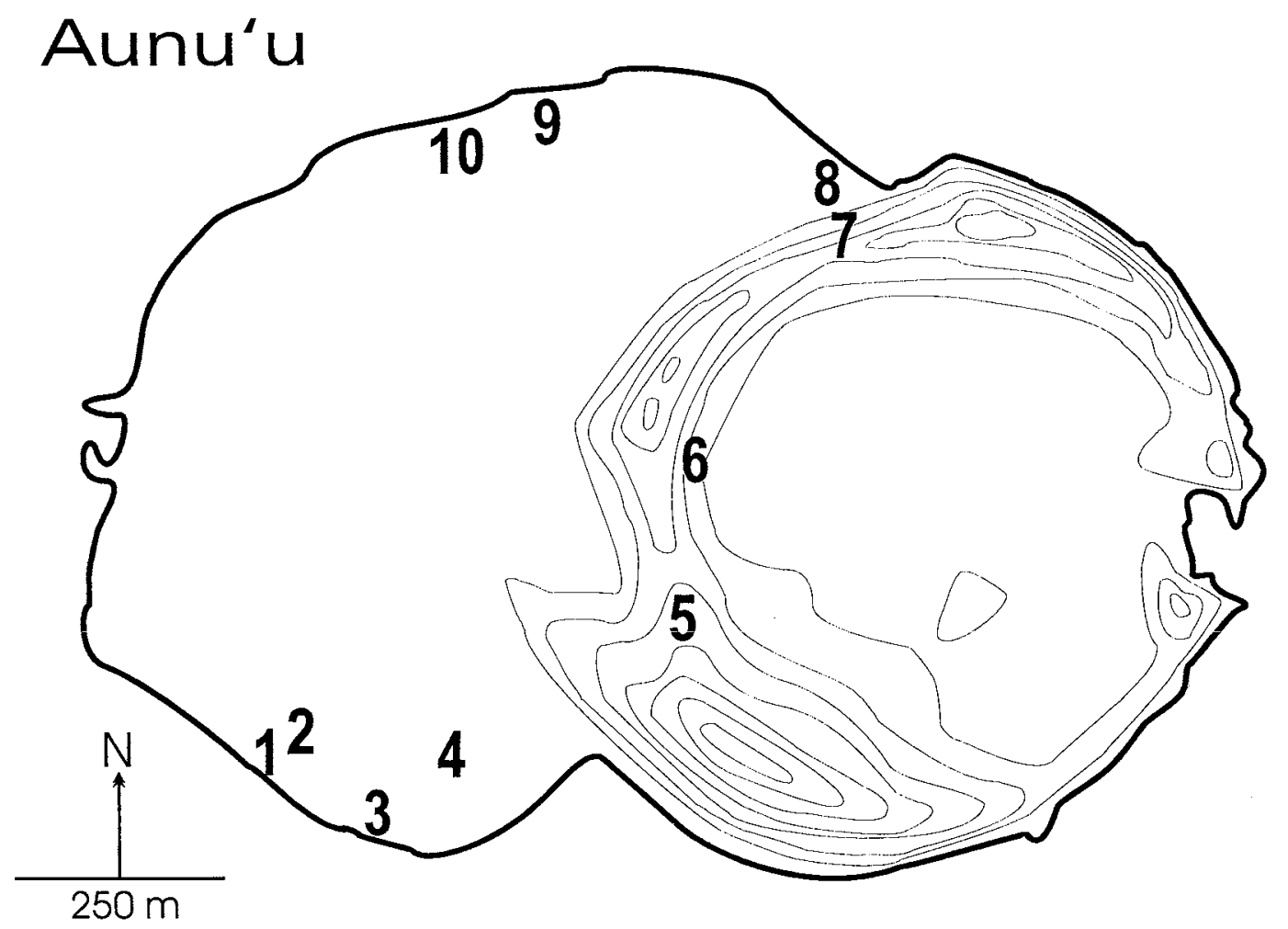

Figure 2. Location of sampling stations on Aunu'u. Contours at $12-\mathrm{m}(40-\mathrm{ft})$ intervals. 
hand collecting. This study, like those other studies, was intended as a species inventory survey. Therefore, in the interests of maximizing number of species detected per unit effort, no litter/soil samples were taken for laboratory analysis (cf. Emberton et al. 1996, Cowie 2001). At most sampling stations, the field team of four people searched the aboveground vegetation for $10 \mathrm{~min}$ and the groundlevel litter/soil for a further $10 \mathrm{~min}$. Additional untimed samples were taken incidentally when interesting species were encountered.

The samples were taken to the laboratory for sorting and identification. Confirmation of identifications was based on comparison with previously identified material (including type material) in the extensive Pacific island land snail collections of the Bishop Museum. Species were determined as native or alien to the Samoan Archipelago based on previous knowledge (Cowie 1998) of their presence/ absence before human colonization of the Islands and their known phylogeographic origins.

All samples have been deposited in the Bishop Museum mollusk collections (accession number 2001.067; catalog numbers вРВМ 261730-261779). Representative specimens of most species are also deposited at the American Samoa Community College (Land Grant Program) and at the National Park of American Samoa.

\section{RESULTS}

Table 1 lists the species collected on Aunu'u during the 2001 survey, as well as those previously known from the island. It also indicates their biogeographic status: endemicoccurs naturally only in the Samoan Archipelago; indigenous-occurs naturally in the Samoan Archipelago but also elsewhere; alien-artificially introduced to the Samoan Archipelago. For a few species a definitive evaluation of their status is not possible.

Seventeen species were collected (Table 1 ), including seven of those previously collected (though not reported in the literature) and 10 collected on the island for the first time. Neither of the two species previously reported in the literature (both Charopidae) were found. Neither the giant African snail, Acbatina fulica Bowdich, nor the alien predatory snail Euglandina rosea (Férussac) was recorded.

The survey, combined with review of museum collections, increased the reported land snail fauna of Aunu'u from 2 to 22 species. Of these species, 11 are native to the Samoan Archipelago, 10 are introduced, and one is "cryptogenic" (of unknown native or alien status [Carlton 1996]).

\section{DISCUSSION}

The island of Tutuila is home to 70 species of land snails (Cowie 1998, 2001, Cowie and Cook 1999). Of these, 16 are alien to the Samoan Archipelago and seven are cryptogenic. The small island of Aunu'u harbors a subset of these species, with a proportion of natives to aliens/cryptogenics (11 to 11 ) that, although more dominated by aliens, is not significantly different from that of Tutuila (log-likelihood G-test (Sokal and Rohlf 1981): $G=3.13, \mathrm{df}=1, P>0.05)$. However, with the exception of the single species endemic to Aunu'u itself (Sinployea aunuuana Solem) and two species endemic to the Samoan Archipelago, the native species of the island are mostly widespread Pacific species. This is not unexpected, because most low islands and most of the lowland areas of Pacific islands do not exhibit high levels of land snail endemism but are inhabited by more widespread (though native) species, and increasingly by alien species (Cowie 2000, in press); the maximum elevation of Aunu'u is less than $100 \mathrm{~m}$.

It seems surprising that such an easily accessible island should have been so poorly known and reported on before this survey. Although no undescribed species were discovered and the fauna consists mostly of wellknown aliens or widespread indigenous species, the lack of prior knowledge suggests that many other more remote and less accessible islands in the Pacific may be even less well known. Such a lack of knowledge is a serious impediment to conservation of these often highly endemic but seriously threatened island faunas. 
TABLE 1

Land Snail Species of Aunu'u Collected before 2001 and during the 2001 Survey, with Site-by-Site Occurrences and Biogeographic Status

\begin{tabular}{|c|c|c|c|}
\hline Taxa & $\begin{array}{l}\text { Recorded } \\
\text { before } 2001^{a}\end{array}$ & $\begin{array}{l}\text { Sites recorded } \\
\quad \text { in } 2001\end{array}$ & Status ${ }^{b}$ \\
\hline \multicolumn{4}{|l|}{ Family Helicinidae } \\
\hline $\begin{array}{l}\text { Orobophana musiva (Gould) } \\
\text { Pleuropoma fulcora (Gould) }\end{array}$ & c & $4,5,9$ & End \\
\hline Pleuropoma fulgora (Gould) & & 5 & Ind \\
\hline \multicolumn{4}{|l|}{ Family Truncatellidae } \\
\hline Truncatella guerinii Villa \& Villa & c & $1,2,3,4,7,8,9$ & Ind \\
\hline \multicolumn{4}{|l|}{ Family Assimineidae } \\
\hline Assiminea parvula (Mousson) & c & $2,7,8$ & \\
\hline Omphalotropis sp. & c & & End/Ind \\
\hline \multicolumn{4}{|l|}{ Family Veronicellidae } \\
\hline Laevicaulis alte (Férussac) & & 6 & Alien \\
\hline Vaginulus plebeius Fischer & & $5,6,7$ & Alien \\
\hline \multicolumn{4}{|l|}{ Family Ellobiidae } \\
\hline Melampus fasciatus (Deshayes) & c & $1,8,10$ & Ind \\
\hline Melampus luteus (Quoy \& Gaimard) & & $1,8,10$ & Ind \\
\hline \multicolumn{4}{|l|}{ Family Achatinellidae } \\
\hline Lamellidea pusilla (Gould) & & $4,7,8$ & Pol \\
\hline \multicolumn{4}{|l|}{ Family Pupillidae } \\
\hline Gastrocopta pediculus (Shuttleworth) & c & - & Ind/Alien \\
\hline \multicolumn{4}{|l|}{ Family Streptaxidae } \\
\hline Gulella bicolor (Hutton) & & 4,7 & Alien \\
\hline Streptostele musaecola (Morelet) & & 5 & Alien \\
\hline \multicolumn{4}{|l|}{ Family Subulinidae } \\
\hline Allopeas gracile (Hutton) & c & - & Pol \\
\hline Opeas bannense (Rang) & c & - & Alien \\
\hline Paropeas achatinaceum (Pfeiffer) & c & 6,7 & Alien \\
\hline Subulina octona (Bruguière) & & $4,6,8$ & Alien \\
\hline \multicolumn{4}{|l|}{ Family Charopidae } \\
\hline Discocbaropa aperta (Möllendorff) & $\mathrm{r}$ & - & Ind \\
\hline Sinployea aunuuana Solem & $\mathrm{r}$ & - & End \\
\hline \multicolumn{4}{|l|}{ Family Succineidae } \\
\hline Succinea modesta Gould & & $2,3,4,5,6,9$ & End \\
\hline \multicolumn{4}{|l|}{ Family Helicarionidae } \\
\hline Liardetia samoensis (Mousson) & c & $4,6,7$ & Ind \\
\hline Ovacblamys fulgens (Gude) & & 6 & Alien \\
\hline
\end{tabular}

${ }^{a} \mathrm{c}$, Present in the Bishop Museum collections but not previously reported in the literature; $r$, reported in the literature.

${ }^{b}$ End, endemic; Ind, indigenous; Alien, alien; Pol, alien but probably a Polynesian introduction.

\section{ACKNOWLEDGMENTS}

We thank the American Samoa Community College Land Grant Program, and especially Don Vargo, for provision of facilities and for facilitating our work on Aunu'u. In addition, Falaniko Mika, Pasia Setu, Nonu TiaSamoa, and Orlo Colin Steele assisted with fieldwork and/or identification of specimens. We also thank Ray Tulofono (American Samoa Department of Marine and Wildlife Resources) for his continuing support of our Samoan land snail work.

\section{Literature Cited}

Carlton, J. T. 1996. Biological invasions and cryptogenic species. Ecology 77:16531655.

Cowie, R. H. 1998. Catalog of the nonmarine snails and slugs of the Samoan Islands. Bishop Mus. Bull. Zool. 3:i-viii, 1-122.

. 2000. Non-indigenous land and freshwater mollusks in the islands of the Pacific: Conservation impacts and threats. Pages 143-172 in G. Sherley, ed. Invasive species in the Pacific: A technical review 
and regional strategy. South Pacific Regional Environment Program, Apia, Samoa. 2001. Decline and homogenization of Pacific faunas: The land snails of American Samoa. Biol. Conserv. 99:207-222. in press. Invertebrate invasions on

Pacific islands and the replacement of unique native faunas: A synthesis of the land and freshwater snails. Biol. Invasions.

Cowie, R. H., and R. P. Cook. 1999. The distribution and abundance of land snails in the National Park of American Samoa, with particular focus on Partulidae. Coop. Natl. Park Resour. Stud. Unit, Univ. Hawaii at Manoa, Tech. Rep. 125:i-iii, 1-143. . 2001. Extinction or survival: Partulid tree snails in American Samoa. Biodiv. Conserv. 10:143-159.
Cowie, R. H., R. J. Rundell, F. Mika, and P. Setu. in press. The endangered partulid tree snail Samoana tburstoni on Olosega and the land snail diversity of the Manu'a Islands, American Samoa. Am. Malacol. Bull.

Emberton, K. C., T. A. Pearce, and R. Randalana. 1996. Quantitatively sampling landsnail species richness in Madagascan rainforest. Malacologia 38:203-212.

Sokal, R. R., and F. J. Rohlf. 1981. Biometry. 2nd ed. Freeman, New York.

Solem, A. 1983. Endodontoid land snails from Pacific islands (Mollusca: Pulmonata: Sigmurethra). Part II. Families Punctidae and Charopidae. Zoogeography. Field Museum of Natural History, Chicago. 